〈症例

\section{EUS-FNAで診断し得た 肝細胞癌胃壁浸潤の 1 例}

須藤梨音 片山裕視* 北濱彰博 小堀郁博

行徳芳則 大川 修 北川智之 中元明裕

斉藤浩紀 玉野正也

獨協医科大学越谷病院/消化器内科

*Corresponding author : yasumi@dokkyomed.ac.jp

〔Key Words〕EUS-FNA, 肝外発育型肝細胞

\section{はじめに}

Endoscopic ultrasonography-guided fine needle aspiration (EUS-FNA) は近年, 消化管間質腫瘍や膵癌 の診断に広く利用されている ${ }^{1,2)}$.また縦隔リンパ節や 縦隔腫瘍生検へも応用されている ${ }^{3,4)}$ ：今回我々は胃壁 から肝外側区域に連続する巨大腫瘍の鑑別診断に EUS-FNAが有用であった 1 例を経験したので報告す る.

\section{症 例}

患者：60歳, 男性.

主訴：黑色便, 黒色嘔吐.

既往歴：脂肪肝，糖尿病。

嗜好歴：飲酒焼酎 2 合/日，喫煙なし。

現病歴：糖尿病, 高血圧で近医にて内服加療中で あった. 2015年 9 月下旬頃から数日間にわたり黒色便 が持続していた．入院当日嘔吐を数回認めた後，黒色 嘔吐となったため救急要請し，当院搬送となった。

入院時現症：頻脈あり, 右季肋部で肝を 2 横指触知 する。そその他特記すべき所見なし．

血液検查所見：AST優位のトランスアミナーゼの上 昇, 胆道系酵素の上昇, 低アルブミン血症を認めた。B 型, C型肝炎ウイルス, 抗核抗体, 抗ミトコンドリア 抗体はいずれも陰性であった。

入院後経過：病歴から上部消化管出血が疑われたた め，上部消化管内視鏡検查を施行した。胃体上部から 噴門部にかけて胃粘膜下腫瘍様の隆起を認めた (Color 1)。 その口側に潰瘍性病変を認め, 出血源と判 断した (Color 2). 同部位からの生検結果では腫瘍性病 変は認めなかった。また血液検査で肝障害を認めてい たため, 腹部超音波検査, 造影CT検査で精査を施行し た.

腹部超音波所見：肝両葉腫大, 多発腫瘍性病変, 左 葉外側から肝外に連続する $8 \mathrm{~cm}$ 大の腫瘍性病変を認

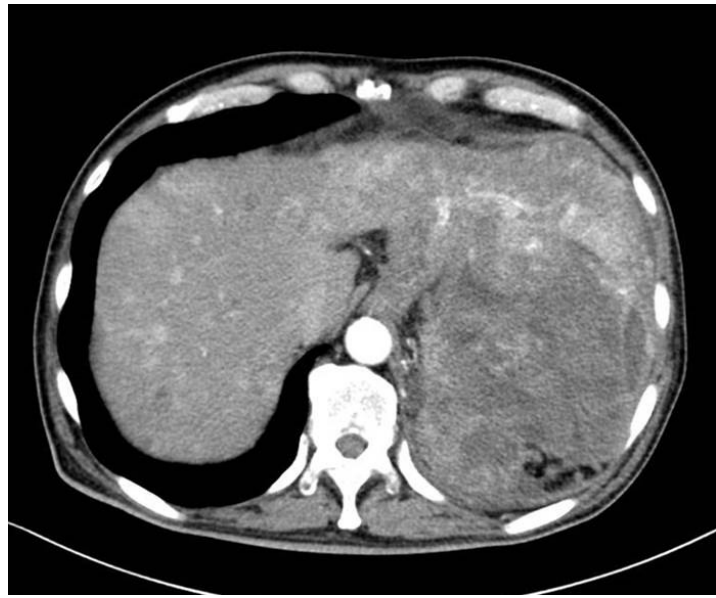

Fig. 1 Computed tomogramphy (CT) findings shows a massive tumor ranging from the cardia to the left heaptic lobe.

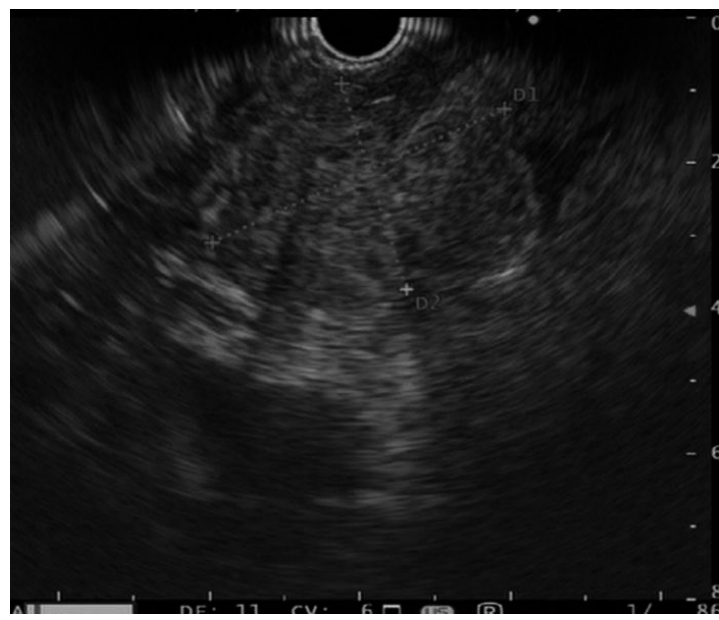

Fig. 2 EUS shows a massive tumor exsists in posterior wall of just below the cardia, and the border between the tumor and the gastric wall is unclear.

めた。造影CT所見:動脈相で濃染し，平衡相で造影剂 がwash outされる肝細胞癌の造影パターンを呈する 多発肝腫瘍，左葉外側と連続する巨大腫瘤を認め，胃 噴門部と腫瘍の境界は不明瞭であった (Fig. 1).

以上の所見から消化管間質腫瘍 (GIST) や肝細胞癌 等を鑑別にあげ，EUS-FNAを行う方針とした。

超音波内視鏡所見 : 噴門部直下後壁に $4 \mathrm{~cm}$ 大の腫瘍 性病変を認めた。胃壁との境界，層構造は不明であっ た(Fig. 2).

病理組織学的所見：HE染色では好酸性胞体に核小 体が目立つ核をもつ腫瘍細胞が胞巣状の配列を示して 増殖し, 免疫染色ではAE1/AE3陽性, CK7, CK20陰 性, CD10一部で陽性となり, 肝細胞癌の胃浸潤として 矛盾しない所見であった $($ Color 3$)$. 
腫痬マーカー：CEA，CA19-9は陰性であり，AFP, PIVKA II は著増していた。

以上より, 肝細胞癌の胃直接浸潤と診断した。肝予 備能は不良であったが, 患者の強い希望もあり肝動脈 化学動注 $(\mathrm{TAI})$ を施行した. しかし，その後消化管出 血や腫瘍出血を繰り返し, 肝不全を来し第31病日に死 亡した。

\section{考 察}

肝細胞癌は通常, 肝内で膨張性発育を来す腫瘍とし て知られているが，本症例のように腹腔内に向かって 発育進展したものは肝外発育型肝細胞癌と呼ばれ，そ の頻度は肝細胞癌全体の $10.4 \%$ と言われている ${ }^{5}$. とき に周辺臟器に直接浸潤を来す場合があり，肝細胞癌患 者のうち直接胃・腸管浸潤を来すものは約 $0.7 \sim 2 \%$ と されており，比較的稀な進展形式であったといえる5

本症例は肝外発育型肝細胞癌であったため, GISTの 肝転移との鑑別が困難であった．胃粘膜下腫瘍との鑑 別が困難であった肝腫瘍について，1983年から2012年 まで肝腫瘍 (liver tumor), 胃粘膜下腫瘍 (gastric submucosal tumor)のキーワードでPubMedと医学中 央雑誌で検索した結果13例認め，9例にEUSが施行さ れているが, FNAまで施行されたのは 1 例のみであっ だ

\section{おわりに}

肝外発育型肝細胞癌において, 胃SMTと鑑別を要す る場合にはEUS-FNAは試みる価值があると思われた

\section{文 献}

1 ) Ando N, Goto H, Niwa Y, et al: The diagnosis of GI stromal tumors with EUS-guided fine needle aspiration with immunohistochemical analysis. Gastrointest Endosc, $55: 37-43$, 2002

2) Williams DB, Sahai AV, Aabakken L, et al : Endoscopic ultrasound guided fine needle aspiration biopsy : a large single centre experience. Gut, $44: 720-726,1999$

3 ) Eloubeidi MA, Cerfolio RJ, Chen VK, et al : Endoscopic Ultrasound-Guided Fine Needle Aspiration of Mediastinal
Lymph Node in Patients With Suspected Lung Cancer After Positron Emission Tomography and Computed Tomography Scans. Ann Thorac Surg, $79: 263-268,2005$

4 ) Larsen SS, Krasnik M, Vilmann P et al : Endoscopic ultrasound guided biopsy of mediastinal lesions has a major impact on patient management. Thorax, 57:98-103, 2002

5 ) Chen LT, Chen CY, Jan CM et al : Gastrointestinal tract involveament in hepatocellular carcinoma. Clinical, radiological and endoscopic studies.Endoscopy, $22: 18-123,1990$

6 ）木田明彦, 松田耕一郎, 平井 聡, 他 : 胃粘膜化腫瘍との鑑 別にセルブロック法を用いた超音波内視鏡下穿刺吸引細胞 診が有用であった肝細胞癌の 1 例. 日消誌, 109:952-960, 2012

$$
\text { 〈カラーはp. 14に掲載〉 }
$$

\section{Direct invasion of HCC to the gastric wall diagnosed by endoscopic ultrasonography-guided fine needle aspiration}

Rion Sudo
Akihiro Kitahama
Yoshinori Gyotoku
Tomoyuki Kitagawa
Akihiro Nakamoto

\author{
Yasumi Katayama* \\ Ikuhiro Kobori \\ Osamu Okawa \\ Hiroki Saito \\ Masaya Tamano
}

A 60-year-old man was transported to our hospital with hematemesis. Upon admission, emergency esophagogastroduodenoscopy revealed an elevated, submucosal lesion just below the gastroesophageal junction. The top of the lesion was ulcerated and this seemed to be the source of the bleeding. Laboratory data showed liver dysfunction and enhanced computed tomography revealed a massive tumor ranging from the cardia to the left hepatic lobe. Endoscopic ultrasonography-guided fine needle aspiration (EUS-FNA) of the tumor through the gastric wall revealed pathological hepatocellular carcinoma (HCC) and direct extrahepatic HCC invasion of the gastric wall was diagnosed. Extrahepatic HCC is rare among the types of primary liver cancer. EUS-FNA helped to achieve an accurate diagnosis. We believe that EUS-FNA is useful, not only for pancreatic cancer and submucosal tumors of the digestive tract, but also for extrahepatic hepatocellular carcinoma.

Department of Gastroenterology, Dokkyo Medical University Koshigaya Hospital

*Corresponding author : yasumi@dokkyomed.ac.jp 